\title{
Laurie Glimcher to take the helm of Weill Cornell Medical College
}

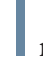
January 2012, Laurie Glimcher (Figure 1) will take a new position as the Dean of Weill Cornell Medical College in New York City. A celebrated immunologist who stresses the importance of interdisciplinary and collaborative science, Glimcher has contributed to the understanding of diverse fields from skeletal biology to metabolism. Glimcher recently spoke to the JCI about her science, her move, and her goals in the big city.

JCI: You've spent most of your career in the Harvard system. Why is now the right time to move?

Glimcher: It was the right job at the right time. If this had come up three or four years ago, I wouldn't have even looked at it. But it struck me as an enormous opportunity. I could keep on doing exactly what I'm doing now, and I would still be very happy, but I felt that I should be thinking beyond my own lab at this point. I'm concerned about the future of academic medical centers in this country and the health of biomedical research, given the tremendous financial constraints that we've experienced in the last few years (and that I'm sure will continue) at the NIH. I wanted to play on a broader stage, really try to enable the science of others, and encourage the best translational research. I feel that requires bringing many different forces together - clinicians, basic scientists, philanthropists, pharma - anything that we can call on to facilitate the transfer of basic discoveries into the clinic. We should be able to do that, to use public-private partnerships to advance science and medicine, and I thought that given my background in biomedical science and my relationships to the private sector, I would be in a position to do that at Weill Cornell.

JCI: Are you bringing your lab with you to New York?

Glimcher: I am. It's not going to be as big a lab as I have now, because I don't think I can do everything, but I can't imagine not continuing the research, because we have some really exciting projects at the moment. I'll need to focus, to select the couple of areas I think are the most interesting.

JCI: Your training was in immunology, but your research portfolio is quite diverse. How have your interests evolved during your career?

Glimcher: I fell in love with immunology when I was a first year medical student at Harvard. I wanted to be a physician, but after internship and residency I went to the $\mathrm{NIH}$, where I did a wonderful postdoc with Bill Paul. I've always sort of gone where the science has taken me, and a good example of that is the Xbp1 transcription factor that we cloned ... following that pathway has led us into a lot of other systems, including lipid biology, diabetes, and now neurodegenerative disease.

And then about six years ago, skeletal biology became a major interest in the lab. My dad is a skeletal biologist, so I guess I

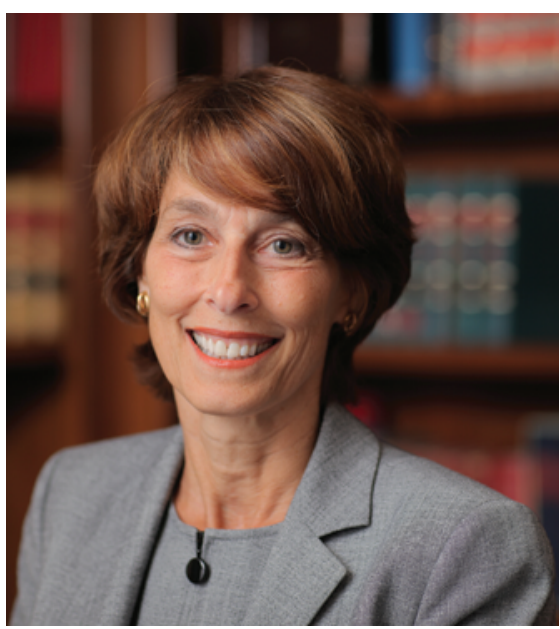

Figure 1

Laurie Glimcher. Photo credit: John Abbott.

have the genes for it. We had dabbled in it before, but things really clicked when we knocked out a factor called Schnurri-3. We didn't see the big blow-away immune phenotype when we deleted the gene that we expected. Then one day, the postdoc and the grad student working on the KO mouse came into my office, and I asked them what the bone marrow looked like. They said, "You know, we can't really access it - for some reason the bone marrow seems filled in." I suggested that they walk down to my father's office at Children's Hospital and take an X-ray of the mice. The mice had incredibly elevated bone density, and we then spent the next couple of years figuring out the mechanism by which that occurred. The work attracted a lot of interest from pharma, because osteoporosis is so common. We started a really wonderful collaboration with Merck, and I built a bone team that is now about half of my lab. The collaboration with Merck was more than just funding; our scientists worked with their scientists, and I think that could be a good model for that sort of partnership.

JCI: Do you have a vision for what you'd like to create at Weill Cornell?

Glimcher: Weill Cornell is in the perfect position for expansion because the current dean, Tony Gotto, and the board of overseers, chaired by Sandy Weill, have done such a wonderful job raising funds to build a new medical research building. That will allow us to recruit some really top-notch faculty to join the already excellent faculty there, and to forge ties with other institutions in New York City. Weill Cornell already has an outstanding clinical group, they have great medical students, and their biomedical research enterprise could very quickly become first rate.

I hope to expand our clinical reach over the next few years to the medically underserved populations in New York. Also, medical education is very important to me. We need to figure out how to help medical students pay for medical school; I think too many of them end up in specialties that they wouldn't necessarily have considered except that they have $\$ 200,000$ in educational loans, so less lucrative specialties like primary care and pediatrics suffer.

JCI: How does it feel to be the first female dean of Weill Cornell Medical School?

Glimcher: It feels great. I've gotten so many e-mails from people offering their kind words. You know, I'm very interested in mentorship - I have been committed to it my entire career - and I admit that I have a special warm spot in my heart for women. I have worked very hard in my own group to make sure that the women have an equal playing field. I want to think a lot about that when I'm at Weill Cornell, about how we can emphasize diversity and really put our money where our mouth is to strengthen it.

\section{Kathryn Claiborn}

